\title{
文献抄 録
}

\section{同種による幼生加入の促進：多毛類 Phragmatopoma californica (Fewkes) の群居性}

Jensen, R. A. and D. E. Morse (1984). Intraspecific facilitation of larval recruitment: gregarious settlement of the polychaete Phragmatopoma californica (Fewkes). J. Exp. Mar. Biol. Ecol. 83, 107-126.

カンムリゴカイ科の多毛類 Phragmatopoma californica (Fewkes) の幼生は同種の棲管の先端部分に接触す ることで着底, 変態し, 基盤上に付着した幼虫となる。 そのような接触がない場合には, 幼生は変態を遅らせる ことが可能であった。同種の個体が棲管を作るときに使 ったガラスビーズが幼生の変態を誘起したのに対し, 海 水で洗い表面に微生物フィルムを形成させた対照区のガ ラスビーズでは幼生の変態は低い割合でしか誘起されな かった。同種の棲管の後ろの部分, 砂岩, 同じ場所に存 在する藻類, 他の無脊椎動物, 他の数種の多毛類の棲管 は幼生の変態を誘起しなかったか, 誘起しても同種の棲 管に比較して低い割合であった。

変態を誘起する刺激は熱によって不活性化した。すた 変態を誘起する刺激の幼生による認識は刺激への接触に 依存したが, 光には依存しなかった。これらのことから 変態を誘起する刺激の少なくとも一部分は化学物質であ ることが示唆された。本種が棲管を形成する際に分泌す るセメント物質に由来するキノン硬化タンパク質, ある いはその前駆体かその生成に携わる酵素が，棲管中の変 態誘起活性に関与しているものと考えられた。

幼生の加入が場所に特異的であることの生態学的な意 義についても考察した。P. californica の幼生が群居性 を示すことは，成体の個体群が固まって分布する結果と なる。単一種が優占する塊が形成され維持されると, 場 に出現する生物相の多様性が低下し, 最終的に個体が維 持しらる空間が確保されることになるものと考えられ た。

(岡本 研)

\section{Phragmatopoma californica 棲管の生物接着物質：L- DOPA を含む絹に類似したセメント物質}

Jensen, R. A. and D. E. Morse (1988). The bioadhesive of Phragmatopoma califolnica tubes: a silklike cement containing L-DOPA. J. Comp. Physiol. B, 158, 317-324.

カンムリゴカイ科の多毛類 Phragmatopoma califor- nica (Fewkes) は砂粒や貝殼の破片などを集めてセメン ト物質で固めた管の中に棲息する。そのセメント物質を CHN コーダーで分析した結果，含まれる全炭素および 全窒素はタンパク質で説明することが可能であった。七 メント物質は複数のタンパク質から構成されていたが, アミノ酸分析の結果から, 綟繊維の外側を取り巻く粘着 性のタンパク質であるセリシンに組成が類似していた。 全残涬の内, 短鎖アミノ酸が $60 \%$ を占めた (グリシン: 24\%，アラニン：7\%，セリン：29\%）。リジンがそれに 続く成分で $(12 \%)$, 塩基性アミノ酸は全残涬の $19 \%$ を 占めた。ヒドロキシル側鎖を持つアミ，酸は全体の $35 \%$ を占めた。DOPA (3,4-dihydroxyphenylalanine) は全残 涬の $2.6 \%$ を占め, キノン硬化や, 基質との接着性の複 合体の形成，あるいはその両方によって，セメント物質 を安定化させているものと考えられた。したがってセ メント物質は構造的にも, 機能的にも, Mytilus spp. (Waite, 1987) や絹と類似性を持っていると考えられた。

(岡本 研)

カンムリゴカイ科多毛類, 特に造礁性種 Phragamatopoma lapidosa と非群生種 Sabellaria floridensis 幼生

\section{の着底, 変態}

Pawlik, J. P. (1988). Larval settlement and metamorphosis of sabellariid polychaetes, with special reference to Phragmatopoma lapidosa, a reef-building species and Sabellaria floridensis, a non-gregarious species. Bull. Mar. Sci. 43 (3), 41-60.

西大西洋産のカンムリゴカイ科の多毛類, 造礁性種の Phragmatopoma lapidosa と非群生種の Sabellaria floridensis 幼生の, 変態誘起因子に対する反応をみた。P. lapidosa の反応は $P$. californica の反応ときわめて似て いた。同時に行った試験では, P. lapidosa と P. californica の間では, 同種の棲管の砂粒は他種の棲管の砂粒よ りも幼生の変態を高い割合で誘導したが，他種の棲管の 砂粒でも対照区に比べて高い割合で変態を誘導した。 $P$. lapidosa の棲管の砂粒・セメント物質を有機溶媒抽出す ると, 同種の幼生の変態を誘起する活性は失われた。活 性は抽出した有機溶媒中に保持され，HPLCにより分画 したところ，脂溶性画分の一つに変態誘起活性が認めら れた。変態誘起活性があった画分を GCにより分析した ところ, 変態誘起物質は炭素鎖 14 から 22 の遊離脂肪 
酸の混合物であった。活性のあった画分の成分は，P. californica の棲管から分離された変態誘起画分と同じ 遊離脂肪酸成分であったが，その割合は異なっていた。 画分中の遊離脂肪酸のらち, 幼生の変態誘起率は $16: 1$, $18: 2,20: 4,20: 5$ による場合が最も高く, 16:1 では砂 粒 $1 \mathrm{~g}$ (表面積 $36 \mathrm{~cm}^{2}$ ) あたり $1 \mu \mathrm{g}$ で変態を誘起した。 変態を誘起する遊離脂肪酸は, 抽出が不完全ではあるも のの, P. lapidosa の棲管中に, 棲管の砂 $1 \mathrm{~g}$ あたり約 $4 \sim 5 \mu \mathrm{g}$ 含まれていた。37 種の遊離脂肪酸と 9 種の遊離 脂肪酸の誘導体の標品を用いた試験では, P. lapidosaの 幼生の変態誘起は P. californica と同様に, アシル基の 長さと構造およびカルボン酸の官能基の存在に依存し た。同時に行った P. lapidosa と P. californica の交配 実験から幼生がえられ, 正常に発生して変態した。これ ら二つの結果から, P. lapidosa と P. californica は同じ 種の地理的品種であり，それぞれの亜種に対してPhragmatopoma lapidosa lapidosa \& P.l. californica の三 命名法を提唱した。

Sabellaria floridensis の幼生の反応は三つの点で $S$. alveolata と類似した。(1) 飼育中, 多くの幼生は発生が 進さと飼育容器内で逐次変態した。(2) 室内の着底実験 では多くの幼生が対照区の砂粒上で変態した。(3) Phragmatopoma の幼生の変態を誘起する遊離脂肪酸によっ て変態は促進されなかった。造礁性の S. alveolata とは 異なり, 群居性を示さない S. floridensis の幼生は, 同種 の棲管の砂粒によって变態を誘起されなかった。カンム リゴカイ科の多毛類では, 同種の棲管の砂粒による変 態, 着底の誘起は造礁性と関連してのみみられるものと 考えられた。

(岡本 研)

\section{実験室内および海洋環境中での化学的刺激による多毛 類幼生の変態}

Jensen, R. A. and D. E. Morse (1990). Chemically induced metamorphosis of polychaete larvae in both the laboratory and ocean environment. $J$. Chem. Ecol. 16 (3), 911-930.

海産多毛類 Phragmatopoma californica の浮遊幼生 は, 同種が構築した棲管のセメント物質に接触すること で着底, 変態し, 基盤に付着した幼虫になる。幼生が変 態時に示すこの群居性は, この種の造礁に寄与してい る。幼生の変態は, 多フェノール性タンパク質である棲 管のセメント物質のアミノ酸残涬に $2.6 \%$ 含まれる dihydroxyphenylalanine (DOPA) の架橋化物の芳香族 類似物と考えられる 2,6-di-tert-butyl-4-methylalanine
$(\mathrm{DBMP})$ への接触によっても誘起された。幼生の変態 は, DBMP を固体表面にしみこませた状態でも, DMSO に溶かして海水中に溶解させた状態でも誘起された。ま たDBMPを塗布したプラスティック板を海中に浸漬し た場合にも，板に幼生が着底，変態した。forskolin と isobutylmethylxanthine (IBMX) 恃両方とも $P$. califor nica の幼生の変態を誘起したが, これは細胞内 cyclic AMP (cAMP) を増加させたことによるものと考えられ た。化学的に誘起される変態をコントロールする経路に ついて考察し, その過程で cAMP がセカンドィッセン ジャーとしての役割を果たしている可能性を示唆した。 P. californica の幼生の着底, 変態を誘起することが報 告されているアラキドン酸, リノレン酸, パルミトレイ ン酸を含も細胞内 cAMP のレベルを増加させる化合物 は, 幼生の細胞内 cAMP を直接増加させることによっ て変態を誘起したものと考えられた。

(岡本 研)

\section{遊離脂肪酸による多毛類 Phragmatopoma californica 幼生の人為的変態}

Jensen, R. A., D. E. Morse, R. L. Petty and N. HoOKer (1990). Artificial induction of larval metamorphosis by free fatty acids. Mar. Ecol. Prog. Ser. 67, 55-71.

カンムリゴカイ科の多毛類 Phragmatopoma californica の幼生は同種の棲管に接触することで变態, 着底す る。洗浄したガラスビーズを成体に与えて棲管を形成さ せることにより，不純物を含まない変態誘起物質が得ら れた。このことにより, 膨潤した虫体からの体液の漏出 や，あるいは野外から採集して他の生物が入り混じって いる棲管の塊からの抽出などの問題なく, 天然の変態誘 起因子を部分的にではあるが精製することができた。そ の結果, 以下の理由から, 遊離脂肪酸は P. californica の幼生の群居性の直接的な原因因子ではないことが示さ れた。（1）污染されない状態で得られた天然の変態誘起 因子は遊離脂肪酸を含まない。野外から採集された棲管 に含まれる遊離脂肪酸の含量は虫体や他の生物によるサ ンプルの污染状態による。(2) 天然の変態誘起因子中の 全炭素量は，実験的な愦差範囲でタンパク質で説明でき る。（3）天然の変態誘起因子とパルミトレイン酸をコー ティングしたガラスビーズの活性は，有機溶媒抽出によ って減少する。パルミトレイン酸をコーティングしたガ ラスビーズとは異なり, 天然の変態誘起因子の抽出では 遊離脂肪酸は抽出されなかったことから，活性の低下は 脂肪酸の抽出によるものではなく, 変態誘起因子が不 
安定で, 有機溶媒によって失活したものと考えられた。 （4）凍結乾燥や攪拌によって，天然の変態誘起因子は失 活したが，パルミトレイン酸をコーティングしたガラス ビーズでは活性に影響がなかった。(5) パルミトレイン 酸による变態誘起は温度に依存したが，棲管による変態 誘起は温度に依存しなかった。(6) 天然の变態誘起因子 は分類群に特異的であったが，脂肪酸による変態誘起は 分類群に特異的ではなかった。サンゴ藻に接触すること で着底, 変態するアワビ Haliotis rufescens の幼生の行 動は, P. californica の棲管に接触しても変化がみられ なかったが, ある種の遊離脂肪酸に接触すると, 濃度に 依存して, 低い割合で着底, 変態がみられた。他の生物 では遊離脂肪酸が情報伝達や膜機能の擾乱を起こすこと が知られていることと, 今回の結果から, 遊離脂肪酸は 天然の变態誘起因子と比較して, 生理学的に下位か相似 の部位を刺激することで変態を誘起するものと示唆され た。膨潤した虫体や他の生物体を含んだ塊の抽出物中の 遊離脂肪酸はお抢らく人為的なもので, これらの組織に 含まれる脂肪分解酵素によって遊離したものであり，天 然で幼生の着底, 変態を誘起する因子の一部ではないと 考えられた。

(岡本 研)

\section{カンムリゴカイ科の多毛類 Phragmatopoma lapidosa californica 幼生の天然および人為的な変態誘起. 海産無 脊椎動物幼生への生理活性物澌の影響に対する批判的見} 解

PAwlik, J. R. (1990). Natural and artificial induction of metamorphosis of Phragmatopoma lapidosa californica (Polychaeta: Sabellariidae), with a critical look at the effects of bioactive compounds on marine invertebrate larvae. Bull. Mar. Sci. 46 (2), 512-536.

近年, 神経伝達物質をはじめとする各種の生理活性物 質によって, 海産無脊椎動物幼生の着底, 変態が誘起さ れることが報告されている。管棲多毛類 Phragmatopoma lapidosa colifornica の幼生の着底, 変態に対する生 理活性物質の影響について検討した。コリン, サクシニ ルコリン, セロトニンは P.l. californica の幼生の変態 を様々な割合で誘起したが，変態した個体は奇形化し た。 $\gamma$-aminobutyric acid (GABA) は幼生の変態を誘起 しなかった。D-/L-3,4-dihydroxyphenylalanine (DOPA) は 10-30\% 程度の割合で正常な変態を誘起したが,ドー パミン, ノルエピネフリン (ノルフドレナリン), エピネ フリン（アドレナリン）では幼生は変態しなかった。LDOPA は海水中で急速に酸化し， 2 時間以上おいた溶液
は失活した。天然の変態誘起物質であるパルミトレイン 酸による変態はきわめて速い反応であるが，L-DOPAに よる変態には数時間を要することから, L-DOPA は幼 生体表の化学受容器に作用するのではないことが示唆さ れた。膜のイオン透過性を変化させる 4 種の化合物の 内, テトラエチルアンモニウム (TEA), スルフォニルイ ソチオシアノスチルベン (SITS), ピクロトキシンの 3 種 は, 幼生の変態に影響しなかった。ウアバインは単体で は幼生の変態を誘起しなかったが, $10^{-5} \mathrm{M}$ の濃度のウア バインをパルミトレイン酸 $(1 \mathrm{mg} /$ 砂粒 $1 \mathrm{~g})$ と組み合わ せた場合，高い割合で幼生を変態させた。しかしそのほ とんどは奇形個体であった。ウアバインは低濃度では幼 生の変態に対して影響を及ぼさず, 高濃度では毒性を示 した。数種類の細胞で細胞内 cAMP 濃度を变化させ ることが知られている 3 種類の化合物の内, ジブチル cAMP (db-cAMP) とコレラトキシンはP.l. californica の幼生に影響を及ぼさなかった。イソブチルメチルキサ ンチン (IBMX) は $10^{-5} \sim 10^{-4} \mathrm{M}$ の濃度で, 正常な変態 を高い割合で誘起した。

得られた結果からは, (1) 海産無脊椎動物幼生の着底, 変態の天然の誘起物質は, 神経伝達物質と構造的に関連 している, (2) 種々の海産無脊椎動物幼生の変態誘起は 単一の共通の経路を通して行われる, といら仮説と反す るものであった。本研究およびこれまでの研究で用いら れた生理活性物質は, 異なる細胞系や組織に対して, し ばしば種々の異なる影響を抢よぼす。幼生個体全体に対 する生理活性物質の影響の試験は, 影響される細胞の点 でも，観察される反応の点でも，特異的なものではな い。したがって現時点で, これらの生理活性物質に対す る海産無脊椎動物幼生の反応に基ついて, 着底, 变態の 誘起を支配する詳細な分子的な経路を提言することは不 可能であると考えられる。

(岡本 研)

\section{Sabellaria cementarium Moore の幼生の着底と他の カンムリゴカイ科の種類との比較}

PAWlik, J. P. and F.-S. ChiA (1991). Larval settlement of Sabellaria cementarium Moore, and comparisons with other species of sabellariid polychaetes. Can. J. Zool. 69, 765-770.

Sabellaria cementarium は一部の海域では造礁性で あるが, 多くの海域では群居性を示さない。S. cementarium の幼生は $15^{\circ} \mathrm{C}$ では 25 日で変態可能となった。 これはこれまでこの種について報告された例よりも早 く, 同様の条件下で飼育された他のカンムリゴカイ科の 
種類の例とほぼ同様であった。3 回の実験の内 2 回で, 同種の棲管の砂粒と対照区，西るいは有機溶媒抽出され た棲管砂粒の間で幼生の着底率に有意な差はみられず， この種類は化学的な因子に反応して群居するのではない ことが示唆された。造礁性の 2 種のカンムリゴカイ科の 多毛類, Phragmatopoma lapidosa lapidosa \& P. l. californica の幼生の着底誘起物質である遊離脂肪酸に よっては, 本種の幼生の着底は誘起されなかっだ。また
同時に行った試験で, S. cementarium とP. l. californica の幼生は同種と他種の棲管砂粒を有意に判別しなかった が，同所的に出現する場所では P.l. californica の塊の 中にはS. cementarium の棲管はみられない。この 2 種 の交配は最高 $14 \%$ が受精するものの, 幼生は餒化直後 に死亡し, 不可能である。S. cementarium の幼生が $P$. l. californica の棲管を避けて着底する過程, あるいは その逆の過程は不明である。

(岡本 研) 